\title{
Global health care challenge: Indian experiences and new prescriptions*
}

\author{
Sandhya Wakdikar \\ National Institute of Science Technology and Development Studies (CSIR) \\ Dr. K.S. Krishnan Marg \\ New Delhi- 110012, India \\ Tel: 91 25841382/1384, ext. 275 \\ Fax: 91 25846640/1260 \\ E-mail: sandhyaw@nistads.res.in
}

* This is an improved version of the paper presented at the World Herbo Expo 2004 held at Bhopal, India, January 12-14, 2004.

Keywords: health care products, medicinal and aromatic plants, research and development capabilities, traditional knowledge.

Globally, there has been an unparalleled growth in the plant-derived medicinally useful formulations, drugs and health-care products, its market covering more than $60 \%$ products derived from plant origin. India exhibits remarkable outlook in modern medicines that are based on natural products besides traditional system of Indian medicines. Almost, $70 \%$ modern medicines in India are derived from natural products. Medicinal plants play a central role not only as traditional medicines but also as trade commodities, meeting the demand of distant markets. Ironically, India has a very small share (1.6\%) of this ever-growing global market. To compete with the growing market, there is urgency to expeditiously utilize and scientifically validate more medicinally useful plants while conserving these species, which seems a difficult task ahead. This paper begins with an overview of the value of Medicinal and Aromatic Plants and discusses its usefulness in the traditional medicines. Then it briefly assesses the potential of medicinally useful plants and prospects of modern medicines and health care products derived from plant origin and based on the knowledge of alternative system of medicine in India. It thereafter concisely touches upon India's varied biodiversity, comparative Research and Development strength, strong pharmaceutical manufacturing base and traditional wisdom in medicines to improve its market potential. In the conclusion, there are major recommendations to help India evolve as a major drugs and herbal based health care products leader in the world market.

\section{MEDICINAL AND AROMATIC PLANTS: AN OVERVIEW}

India has $2.4 \%$ of world's area with $8 \%$ of global biodiversity. It is one of the 12 mega-diversity hot-spot regions of the world, other countries being Brazil, Colombia, China, South Africa, Mexico, Venezuela, Indonesia,
Ecuador, Peru, USA and Bolivia. Across the country, the forests of India are estimated to harbour 90\% of India's medicinal plants diversity in the wide range of forest types that occur. Only about $10 \%$ of the known medicinal plants of India are restricted to non-forest habitats. The estimated numbers of plant species and those used for medicinal purpose vary. According to Schippmann et al. (2002), one fifth of all the plants found in India are used for medicinal purpose. The world average stands at $12.5 \%$ while India has $20 \%$ plant species of medicinal value and which are in use Table 1. But according to Hamilton (2003), India has about $44 \%$ of flora, which is used medicinally (Table 2). Although it is difficult to estimate the number of medicinal and aromatic plants present worldwide, the fact remains true that India with rich biodiversity ranks first in per cent flora, which contain active medicinal ingredient.

\section{MAPS AND TRADITIONAL MEDICINE}

The existence of traditional medicine depends on plant species diversity and the related knowledge of their use as herbal medicine. In addition both plant species and traditional knowledge are important to the herbal medicine trade and the pharmaceutical industry whereby plants provide raw materials and the traditional knowledge prerequisite information (Tabuti et al. 2003).

India has one of the richest plant medical traditions in the world. It is a tradition that is of remarkable contemporary relevance for ensuring health security to the teeming millions. There are estimated to be around 25,000 effective plant-based formulations, used in folk medicine and known to rural communities in India. There are over 1.5 million practitioners of traditional medicinal system using medicinal plants in preventive, promotional and curative applications. It is estimated that there are over 7800 medicinal drug-manufacturing units in India, which consume about 2000 tonnes of herbs annually (Ramakrishnappa, 2002). 


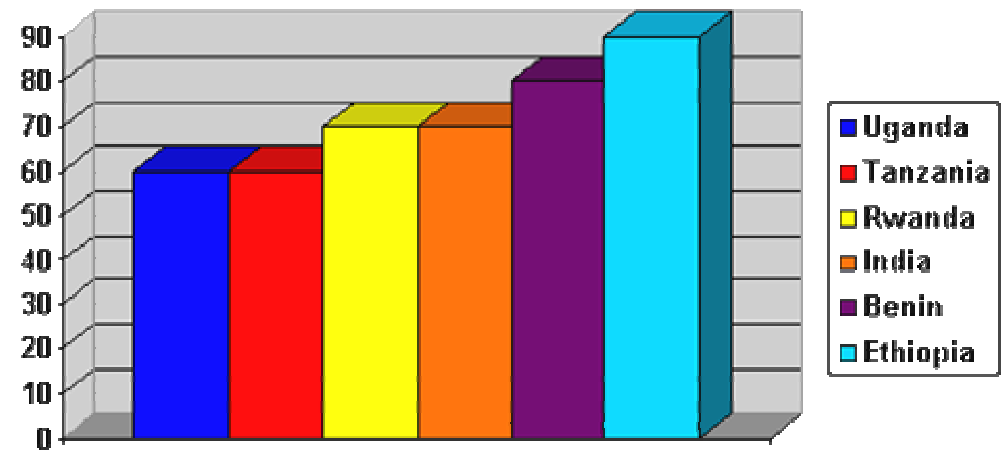

Figure 1. Percent use of traditional medicine for primary health care in few developing countries. Source: WHO, 2002

The market for ayurvedic medicines is estimated to be expanding at $20 \%$ annually. Sales of medicinal plants have grown by nearly $25 \%$ in India in past ten years (1987-96), the highest rate of growth in the world (Masood, 1997). But the per capita expenditure in India on medicines per annum is amongst the lowest in the world. In other developing countries too, plants are the main source of medicine (Figure 1). Two of the largest users of medicinal plants are China and India. Traditional Chinese Medicine (TCM) uses over 5000 plant species; India uses about 7000. According to Export Import Bank, the international market for medicinal plant related trade is to the tune of US\$ 60 billion having a growth rate of $7 \%$ per annum. China's share in world herbal market is US\$ 6 billion while India's share is only US\$1 billion which according to Rawat is 'expected to rise to Rs.3000 crores by 2005' (Rawat, 2002) while TCM is projected to rise to US\$ 400 billion by 2010 (Wang and Ren, 2002).

Traditional and folklore medicine handed on from generation to generation is rich in household remedies and community practice. According to an estimate of World Health Organization (WHO), nearly $80 \%$ of the populations of developing countries rely on traditional medicine, mostly plant drugs for their primary health care needs.

Traditional medicine has served as a source of alternative medicine, new pharmaceuticals, and healthcare products. Medicinal plants are important for pharmacological research and drug development, not only when plant constituents are used directly as therapeutic agents, but also as starting materials for the synthesis of drugs or as models for pharmacologically active compounds (Mukherjee, 2003).

A significant number of modern pharmaceutical drugs are thus based on or derived from medicinal plants. The derivatives of medicinal plants are non-narcotic with little or no side effects.

\section{POTENTIAL AND PROSPECTS OF PLANT BASED MODERN MEDICINES AND HEALTH CARE PRODUCTS: CAN INDIA TARGET THE INTERNATIONAL MARKET?}

It is estimated that nearly three fourths of the plant-derived prescription drugs used worldwide were discovered following leads from local medicine. About $25 \%$ of modern medicines are descended from plants first used traditionally according to WHO. Many others are synthetic analogues built on prototype compounds isolated from plants. Almost, $70 \%$ modern medicines in India are derived from natural products (Choudhary, 2002).

The basic uses of plants in medicine will continue in the future, as a source of therapeutic agents, and as raw material base for the extraction of semi-synthetic chemical compounds such as cosmetics, perfumes and food industries. Popularity of healthcare plant-derived products has been traced to their increasing acceptance and use in the cosmetic industry as well as to increasing public costs in the daily maintenance of personal health and well being. In the dual role as a source of healthcare and income, medicinal plants make an important contribution to the larger development process. Though the efficacy of herbals requires development of quality consciousness in respect of the evaluation related evidences, supplying the demand for botanicals and herbals is a booming business (Mukherjee, 2002).

Recently even developed countries, are using medicinal systems that involve the use of herbal drugs and remedies. Undoubtedly the demand for plant-derived products has increased worldwide. The demand is estimated to grow in the years to come fuelled by the growth of sales of herbal supplements and remedies according to several surveys. This means that scientists, doctors and pharmaceutical companies will be looking at countries like China, India, 
Table 1. Numbers and Plants used medicinally worldwide (Schippmann et al. 2002).

\begin{tabular}{|c|c|c|c|}
\hline Country & Plants species & Medicinal plant species & Percentage \\
\hline China & 26,092 & 4,941 & 18.9 \\
\hline India & 15,000 & 3,000 & 20.0 \\
\hline Indonesia & 22,500 & 1000 & 4.4 \\
\hline Malaysia & 15,500 & 1,200 & 1.7 \\
\hline Nepal & 6,973 & 700 & 6.1 \\
\hline Pakistan & 4,950 & 300 & 9.5 \\
\hline Philippines & 8,931 & 850 & 16.6 \\
\hline Sri Lanka & 3,314 & 550 & 15.5 \\
\hline Thailand & 11,625 & 1,800 & 11.8 \\
\hline USA & 21,641 & 2,564 & 17.1 \\
\hline Vietnam & 10,500 & 1,800 & 12.5 \\
\hline Average & 13,366 & 1,700 & \\
\hline World & 422,000 & 52,885 & \\
\hline
\end{tabular}

etc. for their requirements, as they have the most number of medicinal plant species and are the top exporters of medicinal plants.

\section{WORLD MARKET: EXPORT OPPORTUNITIES FOR DEVELOPING COUNTRIES}

The value of medicinal plants as a source of foreign exchange for developing countries depends on the use of plants as raw materials in the pharmaceutical industry. It provides numerous opportunities for developing nations to advance rural well being. The global trade in medicinal plants is of the order of US\$ 800 million per year. Export statistics available between 1992 and 1995 indicate that India exported about 32,600 tonnes of crude drugs valued at \$US 46 million (Dhar et al. 2002). China with exports of over 120,000 tons per annum (US\$ 264.5 million) and India with over 32,000 tons per annum dominate the international market. The annual export of medicinal plants from India is valued at Rs. 1200 million (Ramakrishnappa, 2002). All the major herbal-based pharmaceutical companies are showing a constant growth of about 15 per cent or more, next only to Information Technology industry (Kumar, 2000). The turnover of herbal medicines in India as over-the-counter products, ethical and classical formulations and home remedies of Ayurveda, Unani, and Siddha systems of medicine is about US\$1 billion with a meagre export of about US\$ 80 million (Kamboj, 2000).

The worldwide market of herbal medicines is of the order of US $\$ 60$ billion (WHO, 2002) to US $\$ 80$ billion (Mathur, 2003). In the West the demand for herbal drugs has reached a new high in recent years. About 1400 herbal preparations are used widely according to a survey in Member States of European Union (Hoareau and DaSilva, 1999). In 1999 the global market for herbal supplements exceeded US\$ 15 billion, with a US\$ 7 billion market in Europe, US\$ 2.4 billion in Japan, US\$ 2.7 in the rest of Asia and US\$ 3 billion in North America (Table 3). The use of herbal medicine is widespread, with as many as three in ten Americans using botanical remedies in a given year (Raskin et al. 2002).

In the USA, sales of botanical products (fortified foods, dietary supplements) increased by more than $40 \%$ between 1992 and 1996 to reach a global value of more than US\$14 billion in 1996. Similar trends were observed in Japan and the Western European countries too (Schilter et al. 2003).

It is estimated that Europe imports about 400,000 tons of medicinal plants per annum, with an average market value of US\$ 1 billion from Africa and Asia. Germany is by far the largest market and within Europe, largest consumer of medicinal plants, spending $£ 1.4$ billion (US\$ 2.2 billion) annually. France is second ( $£ 116$ million) and the United Kingdom third ( $£ 88$ million) (Masood, 1997). Among the importers of botanical drugs, Hong Kong is at the top followed by Japan, Germany and USA. These assessments of international trade in medicinal plants include plants and their parts like roots, tubers, wood extract, bark, leaves, flowers, fruit and seeds. Germany and the USA are among the top four countries in import as well as export, expressing their major role as a turntable for medicinal plant raw materials worldwide.

Several important modern drugs are extracted directly from plants. It has been estimated that only $6 \%$ of all described species have been analysed chemically and only a small fraction analysed pharmacologically (Choudhary, 2002). In the USA, the process of synthetic drug discovery and development takes an average of 12 years, and any new drug requires the investment of an average of US\$ 230 million. It is seen that plant based drugs take a comparatively much less time and expenses than synthetic drugs. Hence plant based medicines would be cheaper, unless the market price are inflated by other considerations (Ramakrishnappa, 2002). 
Table 2. Numbers and percentage of medicinal plant species recorded for different countries and regions (Hamilton, 2003).

\begin{tabular}{|c|c|c|c|}
\hline Country or Region & Total no. of native species of flora & $\begin{array}{c}\text { No. of species of medicinal } \\
\text { plants }\end{array}$ & \% of flora which is medicinal \\
\hline China & 27,100 & 11,146 & 41 \\
\hline India & 17,000 & 7,555 & 44 \\
\hline Mexico & 30,000 & 2,237 & 7 \\
\hline North America & 20,000 & 2,572 & 13 \\
\hline World & $297,000-510,000$ & 52,885 & $10-18$ \\
\hline
\end{tabular}

Some drugs are synthesized copies of chemicals found naturally in plants i.e. aspirin which is a safer synthetic analogue of salicylic acid, an active ingredient of willow bark. The market share of herbal products made in developing countries remains comparatively low due to lack of research and development and the huge investments in making standardized products. Extraction of active principles and manufacture of drug formulations is sophisticated technology and capital intensive. A systematic and a concerted approach to this activity have not been maintained for want of sophisticated equipment and high-cost chemicals. Even in India, there has been a lack of Research and Development on product and process development although recent research has helped propel the knowledge of other plants from around the world and this has helped accelerate the development of new supplements and medicines. In terms of the volume of medicinal plants exported, India ranks second in the world. There is thus an enormous scope for India to emerge as a major player in the global herb based medicines and products by developing its Research and Development capability.

\section{PUBLIC AND PRIVATE SECTOR RESEARCH AND DEVELOPMENT CAPABILITY: BOOSTING QUALITY OF PLANT DERIVED MEDICINES}

Although India has not been able to convert the grey areas of Ayurveda into a major contributor to National Economy, it has in particular, huge opportunities for the development of the pharmaceutical and phyto-chemical industry. The pharmaceutical industry is both large and successful. During the last two decades, it has made massive investments on pharmacological, clinical and chemical researches all over the world in an effort to discover still more potent plant drugs. About 250,000 living plant species contain a much greater diversity of bioactive compounds than any chemical library made by humans but only few plants species have been systematically investigated for the presence of bioactive compounds. A few new drug plants have successfully passed the tests of commercial screening.

The support for agricultural studies for commercial cultivation is needed to reap the benefits of this labour. In fact, agricultural studies on medicinal plants, by its very nature, demand an equally large investment and higher priority. Research in support of industrial development encompasses all activities ranging from the development of superior propagation materials, agro-technology, low cost and efficient processing technologies to improve quality and yield, new formulations to new products and the marketing of finished products. There has been capability building in India in recent years in the Research and Development sector of medicinal formulations involving plants and its compounds both in private sector (i.e. industry oriented) as well as government funded research. There are several private sector and government Research and Development institutions in India of which a few have been mentioned.

Among the industry oriented Research and Development institutes are Dabur Research Foundation, Himalaya Health Care, Zandu pharmaceuticals, Avestha Gengraine Technologies, Reliance Life Sciences, Hamdard, etc.

Dabur Research Foundation carries out research in diverse areas like ayurvedic research which relates traditional knowledge with modern science, pharmaceutical research, phyto-pharmaceuticals, biotechnology, personal care products, new drug and peptide research, food research, clinical research, etc.

The mission of Himalaya Health Care is to satisfy each customer's health needs through well researched, effective and safe remedies harnessed from nature's wealth. The company (claims to be completely research-oriented,) believes that the ideal healthcare system lies in the synergy between ayurveda and modern science.

Zandu's Research and Development activities are dedicated towards, highlighting the usefulness of Ayurvedic herbomineral products by scientific studies and promote and establish natural products beyond India, meeting export obligations.

Avestha Gengraine Technologies has chalked out a plan to address global functional food market in the form of 'food for medicine' under which a major thrust is to derive novel molecule and therapeutics from standardized plant extracts and prepare new cocktails for specific disease like diabetics and skin care.

Reliance Life Sciences is an emerging company focusing 
Table 2. Global market for herbal supplements in 1999 (Raskin et al. 2002).

\begin{tabular}{|c|c|}
\hline Region & Herbal supplements (Billion US \$) \\
\hline World & $>15$ \\
\hline Europe & 7.0 \\
\hline North America & 3.0 \\
\hline Japan & 2.4 \\
\hline Rest of Asia & 2.7 \\
\hline
\end{tabular}

on selected species for research to enhance both the quality and quantities of products of secondary metabolites (like pharmaceuticals, antibodies, anticancer agents, immunemodulators, flavour and fragrances) using Metabolic Engineering.

Apart from these there are several government established Research and Development institutions. Central Institute of Medicinal and Aromatic Plants (CIMAP) is committed to provide global standards for plant based research, processes and products using green technology mode to ensure sustained clientele from agriculture, society and industry. The National Botanical Research Institute (NBRI) has been undertaking both basic and applied research in various aspects of plant sciences for the conservation and sustainable utilization of plant genetic resources for human welfare and sustainable development. One of the major Research and Development activities at Central Drugs Research Institute (CDRI) is the exploration of terrestrial plants, including Indian traditional remedies for novel molecules for drug development. Several Regional Research Laboratories (RRL) are also involved in the regional MAP conservation and proper utilization through Research and Development. RRL-Thiruvananthapuram is involved in search for bioactive/polymer compounds from natural resources and development of new synthetic systems of technological interest; agro-processing of and value addition to spices, coconut, oil palm, cassava, etc. Laboratories at the Indian Institute of Chemical Biology, and the School of Natural Product Studies, Jadavpur University both in Kolkata, Indian Agriculture Research Institute etc. are making major contributions in the field of herbal research. The government of India has set up several Centres through the Indian System of Medicine and Homeopathy of which the National Medicinal Plant Board (NMPB) is one of them. The NMPB was set up to coordinate matters relating to medicinal plants, including developing policies and strategies for conservation, proper harvesting, cost-effective cultivation, Research and Development, processing, and marketing of raw materials to protect, sustain and develop the sector. There are several other agencies both in private sector and of under the government, that are involved in research and development activities of MAPs, along with conservation and upbringing of new plant-based products in national and international markets.

\section{CONSERVING MAPS FOR DRUGI HEALTH CARE DEVELOPMENT}

The global craving for more herbal ingredients creates possibilities for the local cultivation of medicinal crops as well as for the regulated and sustainable harvest of wild. The expanding trade in medicinal plants has serious implications on the survival of several plants species, with many under serious threat to become extinct. According to an all India ethno biological survey carried out by the Ministry of Environment and Forests, Government of India, there are over 8000 species of plants being used by the people of India. 90-95\% collection of Medicinal plants is from the forests (wild-collected). Few are cultivated. The biodiversity loss is not only a threat to ecology of the planet but also a more immediate threat to the livelihood security of rural communities. Data on threatened species are rare but national studies show 120 medicinal plants are rare or endangered in India. Open access to medicinal plants in the wild is perhaps one of the main reasons for the current unsustainable levels of harvesting. As the prices paid to the gatherers tend to be very low, commercial plant gatherers often 'mine' the natural resources rather than manage them, as their main objective is to generate an income resulting in destructive harvesting.

Other factors contributing to unsustainability include lack of sufficient data on wild plant populations, marketing, and trading; inadequate regulations and legal protection (including intellectual property rights for local practitioners with local knowledge); and poor access to appropriate technology for sound harvesting and plantation development. Interaction between social, economic and ecological systems is most essential to conserve the medicinal plants making its sustainable use. A need-based research including screening of plants for biological activity and focus on environmental and bio-diversity conservation aspects of forests, which continue to be primary habitats of medicinal plants, is desirable.

Training to the collectors and growers proves very useful in improving the quality of the material and plummeting the wastage. There is an urgency to have clearly defined 
policies to regulate medicinal plant conservation, cultivation quality control standards, processing and preservation, marketing and trade including domestic and export, and a well-coordinated information network effort.

The modern pharmaceutical industry requires a large quantity of authentic plants too for manufacture of drugs. Opportunities should be given to industry and other beneficiaries to participate more directly in conservation and sustainable use of medicinal plants and their habitat. Reliance Life Sciences and few other industries claim to cultivate MAPs in suitable agroclimatic conditions. Both in situ and ex situ conservation of endangered plant species are in progress.

The National Medicinal Plants Board was set up by the Ministry of Health and Family Welfare, Government of India in 2000 to coordinate and implement policies relating to medicinal plants both at central and state level to facilitate inter ministry, inter state and institutional collaboration and to avoid duplication of efforts. The Forest Department of the Great Himalayan National Park, India, is promoting cultivation of medicinal plants as an income generating enterprise linked to conservation (Hamilton, 2003). Such efforts need to be replicated to speed up the conservation issue. The Foundation for Revitalisation of Local Health Traditions (FRLHT) is an NGO striving towards this issue and is quite successful in some parts of India especially in the south. There are many such foundations and institutions that are helping local people to conserve MAP for sustainable livelihood.

\section{CONCLUDING REMARKS}

Medicinal herbs as potential source of therapeutics aids has attained a significant role in health system all over the world for both humans and animals not only in the diseased condition but also as potential material for maintaining proper health. A major factor impeding the development of the medicinal plant based industries in developing countries has been the lack of information on the social and economic benefits that could be derived from the industrial utilization of medicinal plants. Except for the use of these plants for local health care needs, not much information has been available on their market potential and trading possibilities. As a result, the governments or entrepreneurs have not exploited the real potential of these plants (de Silva, 1997). About two million hectares of forest area on intensive management can produce medicinal plants for export and domestic use to provide health for our millions. Such effort will enhance greenery, generate employment and income to the people and conserve bio-diversity (Kumar, 2000). Further, a roadmap of cultivation of specific species (to start with few important ones) based on exploitable available resources and future demand is urgently required to facilitate a concrete policy coupled with incentive and plan of implementation.

India has the knowledge and skill to develop its Research and Development capabilities. It is the second largest exporter of medicinal plants. Instead of exporting such a large amount of valuable resource with very low returns it can think about developing its own Research and Development capabilities and produce finished goods in the form of modern medicines and health care products derived from plant origin and based on the knowledge of alternative system of medicine. Standardisation of products is most essential to compete in the world market that India has to lay stress on. The finger printing and marker compound analyses are nowadays gaining momentum for standardisation of traditional medicinal formulations. This technique not only helps in establishing the correct botanical identity but also helps in regulating the sanctity of the herb (Mukherjee, 2003). Accrediting body needs to be set up. Products have to be scientifically validated and a campaign to prove the safety of the products needs to be initiated. The Department of Indian System of Medicine and Homeopathy has been specially dealing with the rules and regulations for the herbals along with the Drugs and Cosmetic Act and has come up with the rules for the implementation of good manufacturing practices in herbals, which will not only help to make quality herbal products but also safeguard the adverse effects of the herbals (Mukherjee, 2002). With all these, India has to take up the challenge of leading the drug and herbal market while conserving its rich heritage through proper planning and implementation of policies.

\section{ACKNOWLEDGMENTS}

The author would like to thank Prof. Rajesh Kochhar, Director, NISTADS, for the encouragement and providing infrastructure support.

\section{REFERENCES}

CHOUDHARY, B. The new international seed treaty: Promises and prospects for food security. Current Science, August 2002, vol. 83, no. 4, p. 366-369.

DE SILVA, T. Industrial utilization of medicinal plants in developing countries.In: BODEKER, G.; BHAT, K.K.S.; BURLEY, J. and VANTOMME, P. eds. Medicinal plants for forest conservation and health care. FAO, Non-wood Forest Products Series No. 11, FAO, Rome, 1997, p.158.

DHAR, U.; MANJKHOLA, S.; JOSHI, M.; BHATT, A. and JOSHI, M. Current status and future strategy for development of medicinal plants sector in Uttranchal, India. Current Science, October 2002, vol. 83, no. 8, p. 956-964.

HAMILTON, A. Medicinal plants and conservation: issues 
and approaches [online]. UK, WWF, 2003 [cited 20 November 2003]. Portable Document Format. Available from

Internet:

http://www.wwf.org.uk/filelibrary/pdf/medplantsandcons.p df.

HOAREAU, L. and DaSILVA, E.J. Medicinal plants: a reemerging health aid. Electronic Journal of Biotechnology [online]. 15 August 1999, vol. 2, no. 2 [cited 28 March 2003]. Available from: http://www.ejbiotechnology.info/content/vol2/issue2/full/2/ ISSN 0717-3458.

KAMBOJ, V.P. Herbal medicine. Current Science, January 2000, vol. 78, no. 1, p. 35-39.

KUMAR, A. Plants Based Medicines in India [online]. Features, Press Information Bureau, Government of India, 2000 [cited 19 May 2003]. Available from Internet: http://pib.nic.in/feature/feyr2000/fmay2000/f240520006.ht $\mathrm{ml}$.

MASOOD, E. Medicinal plants threatened by over-use. Nature, February 1997, vol. 385, no. 6617, p. 570.

MATHUR, A. Who owns Traditional Knowledge? Working Paper No. 96, Indian Council for Research on International Economic Relations, January 2003, p. 1-33.

MUKHERJEE, P.K. Quality control herbal drugs: An approach to evaluation of botanicals, Business Horizons, New Delhi, 2002. 800 p. ISBN 81-900788-4-4.

MUKHERJEE, P.K. GMP for Indian Systems of Medicine. In: MUKHERJEE, P.K. and VERPOORTE, R. eds. GMP for Botanicals: Regulatory and Quality Issues on Phytomedicines, Business Horizons, New Delhi, 2003, p. 99-112. ISBN 81-900788-5-2.

RAMAKRISHNAPPA, K. Impact of Cultivation and Gathering of Medicinal Plants on Biodiversity: Case studies from India. In: Biodiversity and the Ecosystem Approach in Agriculture, Forestry and Fisheries [online], FAO, 2002 [cited 25 March 2003]. Available from Internet: http://www.fao.org/DOCREP/005/AA021E/AA021e00.htm

RASKIN, I.; RIBNICKY, D.M.; KOMARNYTSKY, S.; ILIC, N.; POULEV, A.; BORISJUK, N.; BRINKER, A.; MORENO, D.A.; RIPOLL, C.; YAKOBY, N.;O'NEAL, J.M.; CORNWELL, T.; PASTOR, I. and FRIDLENDER, B. Plants and human health in the twenty-first century. Trends in Biotechnology, 1 December 2002, vol. 20, no. 12, p. 522-531.

RAWAT, R.B.S. Medicinal Plants Sector in India with reference to Traditional Knowledge and IPR issues [online]. Paper presented at International Seminar for the
Protection of Traditional Knowledge, New Delhi, April 2002 [cited 28 March 2003]. Available from Internet: http://r0.unctad.org/trade_env/test1/meetings/delhi/India/mi k-094.doc.

SCHILTER, B.; ANDERSSON, C.; ANTON, R.; CONSTABLE, A.; KLEINER, J.; BRIEN, J.O.; RENWICK, A.G.; KORVER, O.; SMIT, F. and WALKER, R. Guidance for the safety assessment of botanicals and botanical preparations for use in food and food supplements. Food and Chemical Toxicology, 2003, vol. 41, p. 1625-1649.

SCHIPPMANN, U.; LEAMAN, D.J. and CUNNINGHAM, A.B. Impact of Cultivation and Gathering of medicinal plants on Biodiversity: Global Trends and Issues. In: Biodiversity and the Ecosystem Approach in Agriculture, Forestry and Fisheries. FAO, 2002, 1-21.

TABUTI, J.R.S.; LYE, K.A. and DHILLON, S.S. Traditional herbal drugs of Bulamogi, Uganda: plants, use and administration. Journal of Ethnopharmacology, September 2003, vol. 88, no. 1, p. 19-44.

WANG, Zhen-Gang and REN, J. Current status and future direction of Chinese herbal medicine. Trends in Pharmacological Sciences, 1 August 2002, vol. 23, no. 8, p. 347-348.

World Health Organization (WHO), WHO Traditional Medicine Strategy 2002-2005 [online]. Geneva, 2002 [cited 10 October 2003]. Portable Document Format. Available from Internet: http://www.who.int/medicines/library/trm/trm_strat_eng.pd f. 